\title{
Perspectives for immunotherapy: which applications might achieve an HIV functional cure?
}

\author{
Vincent Vieillard ${ }^{1}$, Shahin Gharakhanian², Olivier Lucar ${ }^{1,3}{ }^{\text {, Christine Katlama }}{ }^{4}$, \\ Odile Launay ${ }^{5}$, Brigitte Autran ${ }^{1,6}$, Raphael Ho Tsong Fang ${ }^{3}$, Joël Crouzet ${ }^{3}$, Robert \\ L. Murphy ${ }^{7}$ and Patrice Debré ${ }^{1,6}$ \\ ${ }^{1}$ Sorbonne Universités, UPMC Université Paris 06, INSERM, CNRS, Centre d'Immunologie et des Maladies Infectieuses (CIMI- \\ Paris), Paris, France \\ 2 InnaVirVax, Cambridge Innovation Center, Cambridge, MA, USA \\ ${ }^{3}$ InnaVirVax, Génopole, Evry, France \\ ${ }^{4}$ AP-HP, Hôpital Pitié-Salpêtrière, Service des Maladies Infectieuses et Tropicales, Paris, France \\ ${ }^{5}$ Université Paris Descartes, INSERM, CIC 1417, AP-HP, Hôpital Cochin, Paris, France \\ ${ }^{6}$ AP-HP, Hôpital Pitié-Salpêtrière, Département d'Immunologie, Paris, France \\ ${ }^{7}$ Center for Global Health, Feinberg School of Medicine, Northwestern University, Chicago, IL, USA \\ Correspondence to: Vincent Vieillard, email: vincent.vieillard@upmc.fr
}

Keywords: HIV, immunotherapy, functional cure

Received: December 14, 2015 Accepted: February 21, 2016

Published: February 29, 2016

\section{ABSTRACT}

The major advances achieved in devising successful combined antiretroviral therapy (CART) have enabled the sustained control of HIV replication. However, this is associated with costly lifelong treatment, partial immune restoration, chronic inflammation and persistent viral reservoirs. In this context, new therapeutic strategies deserve investigation as adjuncts to CART so as to potentiate immune responses that are capable of completely containing HIV pathogenicity, particularly if CART is discontinued. This may seem a dauntingly high hurdle given the results to date. This review outlines the key research efforts that have recently resurrected immunotherapeutic options, and some of the approaches tested to date. These areas include promising cytokines or vaccine strategies, using different viral or non-viral vectors based on polyvalent "mosaic" antigens and highly conserved HIV envelope peptides, broadly neutralizing antibodies or new properties of antibodies to improve the control of immune system homeostasis. These novel immunotherapeutic strategies appear promising per se, or in combination with TLR-agonists in order to bypass the complexity of the interplay between immune activation, massive $\mathrm{CD}^{+} \mathrm{T}$-cell loss and viral persistence.

\section{INTRODUCTION}

Effective treatment with combined antiretroviral therapy (cART) has achieved impressive reductions in morbidity and mortality among patients infected with human immunodeficiency virus type 1 (HIV-1). Despite these advances, the success of cART is nevertheless frustrated by the need for costly lifelong treatment because it is impossible to completely eliminate the virus from patients, even when viral replication is suppressed at the periphery [1]. cART has also been associated with the development of viral resistance, and the increased risk of several non-AIDS disorders is now well documented, including that of cardiovascular, vascular, hepatic, renal, metabolic, neurological and some oncological diseases, more particularly in individuals who initiated cART at later stages of the infection [2]. This problem was recently demonstrated in a macaque model of SIV infection where even the initiation of treatment during the first three days post-infection was unable to prevent the constitution of a viral reservoir [3]. Furthermore, Lorenzo-Redondo et al showed very nicely that HIV can continue to replicate and replenish the viral reservoir despite potent cART [4]. New immunotherapeutic strategies therefore need to be explored, as an alternative or supplement to cART, targeting a cure and/or normalization of the immune status 
Table 1: Principal factors implicated in the HIV-induced loss of CD4 ${ }^{+} \mathrm{T}$ lymphocytes and immune functions, listed in alphabetical order

Antibody-dependent cellular toxicity and cytotoxic T-lymphocytes via the attachment of circulating gp120 to normal
CD4 ${ }^{+}$T-cells:
Anti-CD $4^{+}$T-cell action via auto-antibodies,
Anti-CD $4^{+}$T-cell suppressive factors by CD $8^{+}$T-cells and/or NK cells.
Apoptosis via immune activation.
Cytokine cytotoxicity.
Cytopathic effect of HIV on CD4 $4^{+}$T-cells and CD4 progenitors.
Destruction of the bone marrow, lymph nodes architecture
Immunosuppression by gp120, gp41, gag, Tat.
Infiltrating malignancies affecting the bone marrow and other sites.
Nutritional deficiencies.
Opportunistic infections of the bone marrow.
Permeability of the CD $4^{+}$T-cell membrane.
Production of cytokines
Selective destruction of memory CD4 $4^{+}$T-cells.
Suppressive effect on immune complexes.

of treated patients.

The first approach concerns a "sterilizing cure" to enable complete eradication of the virus. The prototypical, and unique, example is the well-known "Berlin patient", diagnosed with acute myeloid leukemia and then transplanted with CD34 ${ }^{+}$stem cells from a donor who was homozygous for CCR5 $\Delta 32$, and in whom viral replication remained absent, despite the discontinuation of cART [5]. Recently published follow-ups of this patient strongly suggest that a cure of HIV-1 has indeed been achieved [6]. However, hematopoietic stem cell transplantation is too risky, too complex and too costly for the majority of $\mathrm{HIV}$-infected individuals worldwide, so it is likely that therapeutic strategies targeting eradication will not see widespread use in the near future. Strategies that induce latently infected cells to produce virus have recently generated considerable enthusiasm, including treatments with histone deacetylase (HDAC) inhibitors and other latency reversing agents; however, the clinical effects to date have been modest or not yet demonstrated [7-11].

The second approach is a "functional cure" without the complete eradication of HIV-1, associated with the development of effective host immunity to fight HIV1 [12]. This is based on the strong immune responses observed in a very small proportion of untreated HIVinfected patients, namely long-term non-progressors and elite controllers, who are able to sustain high $\mathrm{CD}^{+} \mathrm{T}$-cell counts and/or control HIV-1 replication below detectable levels [13, 14], and patients who experience long-term virological remission following the discontinuation of antiretroviral therapy that was initiated at an early stage [15].

\section{HOW IMMUNE RESTORATION CAN BE ACHIEVED IN THE HIV SETTING}

HIV-1 infection causes profound and often irreversible changes to the innate and adaptive immune systems. CD $4^{+}$T-cells are progressively depleted, whereas the $\mathrm{CD}^{+} \mathrm{T}$-cell population expands, and much of the immune system is chronically activated. Even under cART, immune activation and chronic inflammation can persist for years, and certainly participate in the continuous replenishment of viral reservoirs, thus constituting an obstacle to an HIV cure [16-18]. The strongest evidence that HIV triggers immune activation has come from recent treatment intensification studies. The addition of raltegravir caused a concomitant reduction in the frequencies of both infected and activated cells [18-20]. The association between residual levels of immune activation and viral persistence after cART thus suggests that these two phenomena may be connected, which is in line with the recent findings of the START study [21]. These observations have increasingly focused clinical research on more robust endpoints that include preservation of the $\mathrm{CD}^{+} \mathrm{T}$-cell count, associated with the control of immune activation and chronic inflammation (Figure 1).

To improve the effectiveness of treatments, a clearer understanding of the mechanisms underlying immune deterioration is necessary; without this knowledge, an efficacious clinical strategy will remain elusive. One of the most intriguing phenomena is the massive depletion of bystander non-infected $\mathrm{CD}^{+}{ }^{+}$T-cells (Table 1). For example, several reports have shown that HIV-1 proteins, including gp120, Tat and Nef, can follow a variety of death pathways to initiate apoptosis in uninfected CD4 ${ }^{+}$T-cells [22-24]. An alternative proposal is that $\mathrm{CD} 4^{+} \mathrm{T}$-cells may be killed by NK cells, and notably by the presence of stress molecules such as NKp44L, the cellular ligand of the activated natural killer (NK) NKp44 receptor [25]. In the context of HIV, this ligand is expressed specifically on bystander non-infected $\mathrm{CD}^{+} \mathrm{T}$-cells $[26,27]$, whereas it is sequestrated by the HIV Nef protein within HIV-infected $\mathrm{CD}^{+}$T-cells. Taken together, these data may, at least partially, explain the preferential depletion of bystander non-infected $\mathrm{CD}^{+}{ }^{+} \mathrm{T}$-cells and development of the viral reservoir $[28,29]$. It is interesting to note that this massive loss of non-infected $\mathrm{CD}^{+} \mathrm{T}$-cells is associated with high 
levels of tissue inflammation and immune cell activation, which could increase both the number of potential HIV target cells susceptible to infection, and the homeostatic proliferation of latently infected cells $[30,31]$.

There are many reasons why the drastic reduction in viral load seen under cART does not result in normalization of the immune system; as well as the classic causes $\left(\mathrm{CD}^{+}\right.$T-cell nadir, HIV RNA level, and host genetic factors), several other factors can be considered:

(i) Age; generally speaking, immune senescence may be both a cause and a consequence of immune activation, leading to a vicious circle [32].

(ii) Co-infections; hepatitis $\mathrm{C}$ virus (HCV) coinfection results in a higher level of immune activation [33]. Likewise, cytomegalovirus has been identified as a cause of $\mathrm{CD}^{+} \mathrm{T}$-cell activation in HIV-infected subjects under cART [34].

(iii) Microbial translocation; the irreversible destruction by HIV of gut-associated lymphoid tissues (GALT), even after years of cART $[35,36]$. This has been linked to the proportion of $\mathrm{CD}^{+} \mathrm{T}$-cells over-expressing CD38 and type I interferons in the blood [37]. Microbial translocation may therefore be a driver of immune activation, and thereby of $\mathrm{CD}^{+}{ }^{+} \mathrm{T}$-cell loss [38]. This systemic activation of tissues in the gastrointestinal tract also contributes to the general increase in inflammation
$[17,39,40]$.

Furthermore, from a qualitative point of view, if $\mathrm{CD}^{+}$T-cell recovery under cART is based on the production of new $\mathrm{CD} 4^{+} \mathrm{T}$-cells, then the T-cell repertoire may at least be partially restored. However, if the rise in the CD4 count results mainly from $\mathrm{CD}^{+} \mathrm{T}$-cell proliferation and survival, the repertoire will remain uncompleted, even though the total number of $\mathrm{CD}^{+}$ T-cells has normalized [41-43].

The complexity of the interplay between immune activation, massive $\mathrm{CD} 4^{+} \mathrm{T}$-cell loss and viral persistence, as outlined in Figure 1, therefore suggests that important account needs to be taken of controlling immune system homeostasis when developing novel immunotherapy strategies to combat AIDS.

\section{IMMUNOTHERAPY IN THE DISEASE SETTING}

\section{Objectives}

Immunotherapy should aim to elicit immune restoration, because the immune responses work in concert to control HIV disease. The great majority of past and

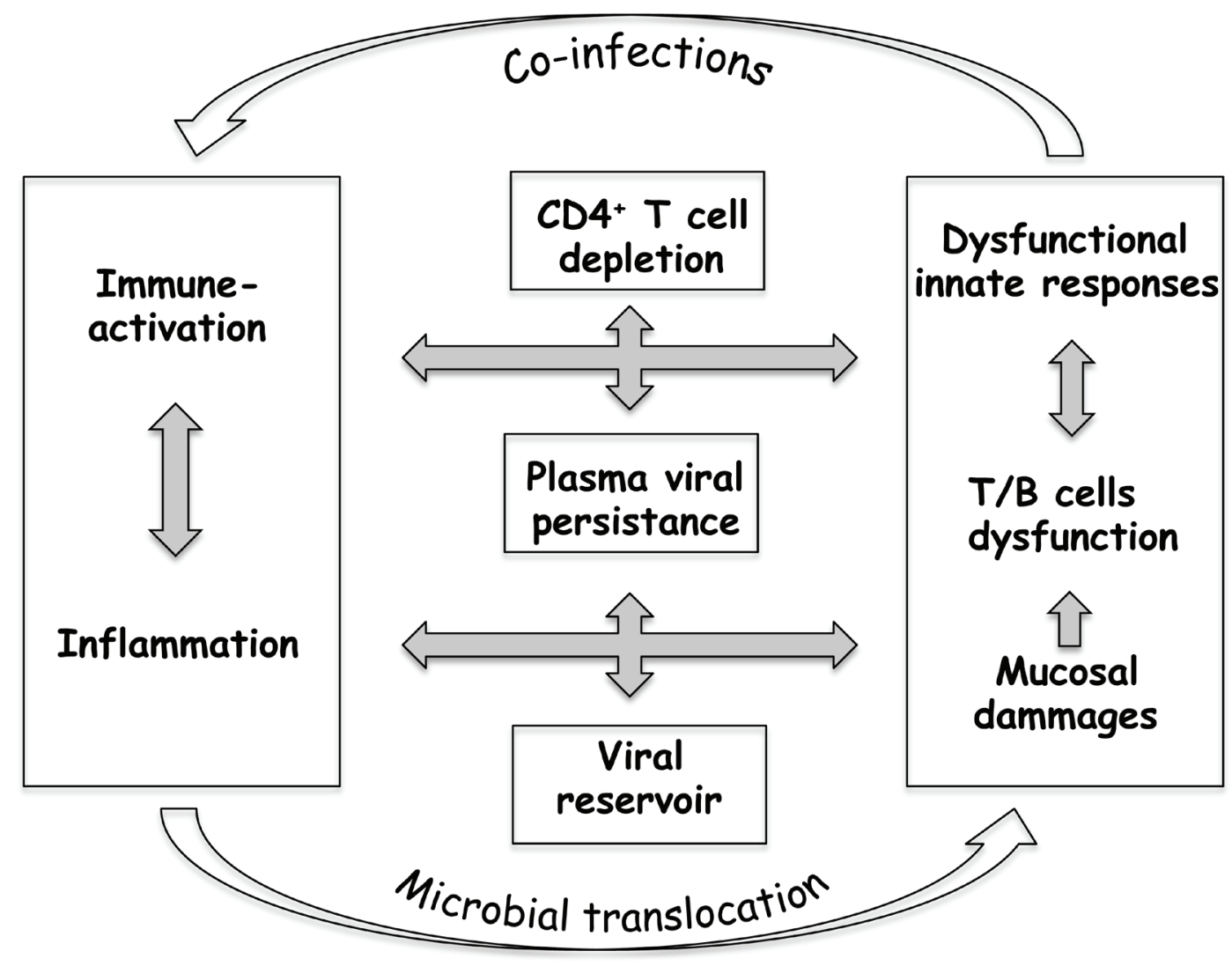

Figure 1: Poor immune restoration under cART sustains a "vicious circle" in HIV-1 infection. 
current strategies have focused on the viral component, but a key question has arisen: is it possible to generate HIV-specific immune responses capable of completely containing viral replication, even in tissue sanctuaries, when cART is discontinued? During randomized trials, no strategy has yet demonstrated its lasting and potent effectiveness in terms of controlling viral load, or delaying clinical progression [44]. This review focuses mainly on immunotherapy to control pathogenicity, prevent immune activation by HIV-1 and reduce inflammation, thereby normalizing the immune system, as an alternative strategy designed to promote directly effective and specific immune responses. It is likely that the efficacy of therapeutic interventions will depend on the disease stage at the initiation of antiretroviral therapy [45]. Different approaches are being tested, including cytokine therapies, therapeutic vaccines, and antibody therapies with different molecular targets.

\section{What about cytokine therapy?}

Cytokines play a pivotal role in modulating immune responses. Both agonist and antagonist therapies directed against cytokines, cytokine receptors or signaling pathways are currently the subject of intense investigation. Treatments based on interleukin (IL)-2, IL-7 IL-15, and IL-21, which all utilize the common CD132 $\gamma$-chain in their receptor complexes, seem to be able to improve the $\mathrm{CD}^{+} \mathrm{T}$-cell count. A trial involving intermittent IL-2 therapy in cART-naive patients was able to demonstrate sustained increases in $\mathrm{CD}^{+} \mathrm{T}$-cell numbers that enabled the deferral of cART [46]. However, larger international randomized trials designed to assess the effects of IL-2 in HIV-1-infected individuals with cART-induced viral suppression revealed no evidence of an improvement in HIV-1 immunity [47], with IL-2 promoting the expansion of $\mathrm{FOXP}^{+}$regulatory T-cell populations [48]. These disappointing findings, as well as the toxicity associated with IL-2 therapy, thus prompted research on the immunomodulating properties of other cytokines such as IL-7 and IL-15 in terms of improving T-cell homeostasis. A dose escalation trial in cART-treated HIV-infected patients showed that IL-7 was well-tolerated and could improve the available TCR repertoire, potentiate cytotoxic T-cell activity and restore $\mathrm{CD}^{+} \mathrm{T}$-cell homeostasis $[49,50]$. On the other hand, supplementation with IL-15 promoted the differentiation of central memory $\mathrm{CD}^{+} \mathrm{T}$-cells into shorter-lived transitional or effector memory $\mathrm{T} \mathrm{CD}^{+}$, which are crucial to immune control [51, 52]. Finally, IL-21 improved T-cell cytotoxicity as well as enhancing antibody production and not increasing viral load in chronically untreated SIV-infected macaques. In particular, higher levels of intestinal Th17 cells were associated with lower rates of intestinal T-cell proliferation, microbial translocation and systemic activation/inflammation [53].

To date, these cytokine-based agents are of uncertain benefit in HIV-infected patients; indeed, high levels of certain cytokines may participate in tissue inflammation and immune cell activation, which in turn could increase

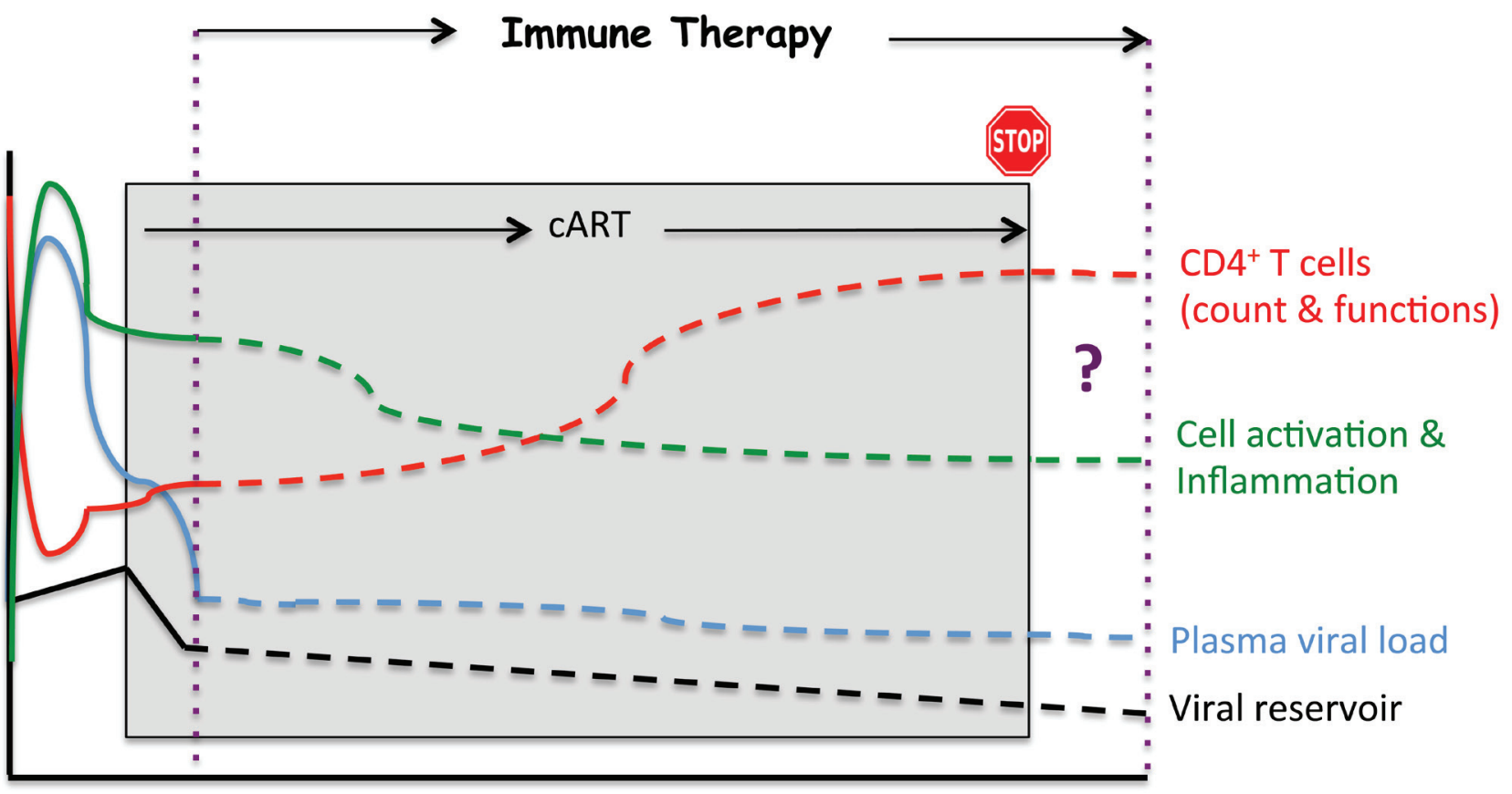

Figure 2: Potential impacts of an immunotherapeutic strategy. 
Table 2: The principal therapeutic vaccines

\begin{tabular}{|c|c|c|c|c|}
\hline Vaccine & Additional description & Phase & \begin{tabular}{|l|} 
Trial Registry \\
Identifier*
\end{tabular} & Reference \\
\hline vCP1452 & ALVAC-based vaccine & 2 & NCT00056797 & \\
\hline MRK Ad5 HIV-1 gag & Adenovirus-based vaccine & 2 & NCT00080106 & {$[56,57]$} \\
\hline ISS T-002 & HIV Tat-based vaccine & 2 & NCT00751595 & {$[58,59]$} \\
\hline GTU-multiHIV B + LIPO-5 & DNA + lipopeptide vaccines & 2 & NCT01492985 & \\
\hline DermaVir LC002 & DNA-based vaccine & $1 / 2$ & NCT00270205 & {$[60-62]$} \\
\hline Synthetic vaccine & HIV Tat-based vaccine & $1 / 2$ & NCT01793818 & \\
\hline THV01 & Lentiviral-based vaccine & $1 / 2$ & NCT02054286 & \\
\hline DNA-GTU & Plasmid DNA-based vaccine & $1 / 2$ & NCT02457689 & \\
\hline AGS-004 & $\begin{array}{l}\text { Patient-derived dendritic cells } \\
+ \text { HIV antigens }\end{array}$ & $1 / 2$ & NCT01069809 & \\
\hline Epimmune & DNA-based vaccine & 1 & NCT00052182 & [64] \\
\hline $\begin{array}{l}\text { rMVA-HIV (env/gag [TBC-M358] + } \\
\text { tat/rev/nef [TBC-M335]) }\end{array}$ & Vaccina Ankara-based vaccine & 1 & NCT00107549 & {$[65]$} \\
\hline $\begin{array}{l}\text { rFPV-HIV (env/gag [TBC-F357] + } \\
\text { tat/rev/nef [TBC-F349]) }\end{array}$ & Fowlpox-based vaccine & 1 & NCT00107549 & {$[65]$} \\
\hline MVA.HIVconsv & MVA-based vaccine & 1 & NCT01024842 & \\
\hline MAG pDNA + rSVIN HIV-Gag & DNA + VSV-based vaccine & 1 & NCT01266616 & \\
\hline HIVAX & Lentiviral-based vaccine & 1 & NCT01428596 & \\
\hline $\begin{array}{l}\text { ChAdV63.HIVconsv + } \\
\text { MVA.HIVconsv }\end{array}$ & $\begin{array}{l}\text { Adenovirus } \\
\text { vaccines }\end{array}$ & 1 & NCT01712425 & \\
\hline iHIVARNA-01 & $\begin{array}{l}\text { TriMix + HIV antigen naked } \\
\text { messenger RNA }\end{array}$ & 1 & NCT02413645 & \\
\hline D-GPE DNA + M-GPE MVA & $\begin{array}{l}\text { DNA and MVA viral vector } \\
\text { vaccines }\end{array}$ & 1 & NCT01881581 & \\
\hline
\end{tabular}

the number of potential HIV target cells susceptible to infection. Recently, Herasimtschuk et al. [54] reported a randomized immunotherapeutic study in cART-treated $\mathrm{HIV}^{+}$individuals designed to investigate the effects of combining IL-2 with therapeutic immunization using a clade B DNA vaccine; their preliminary data suggest that this strategy may improve the $\mathrm{CD} 4^{+} \mathrm{T}$-cell count, restore anti-HIV-1 responses and reduce immune activation. Therefore, carefully administered at the correct time, cytokines might perhaps be combined with other strategies to achieve a clinical benefit.

\section{What about therapeutic vaccination?}

Although no product has yet reached the stage of a phase III clinical trial, a growing number of candidate vaccines are being evaluated in phase I/II or phase II trials conducted in treatment-naive and/or cART-treated patients [55-65] (Table 2), as recently reviewed by Barouch et al. [66]. Some of these viral and non-viral vectors induce $\mathrm{HIV}$-antigen-specific $\mathrm{CD} 8^{+} \mathrm{T}$-cell responses, associated in some instances with HIV-specific B-cell responses. Some of these vaccines have also achieved modest effects on viral load in HIV-infected patients [67]. This argues in favor of improving the vectors and/or antigens. In addition, a combination of such vaccines with other immunotherapeutic approaches could act in synergy (see below). Other strategies are based on HIV peptides; they benefit from a relatively simple design which allows for a thorough characterization of the immune responses induced and avoidance of the complications that have been associated with complex viral vaccine preparations. To date, peptide vaccines to protect $\mathrm{CD}^{+} \mathrm{T}$-cells have received relatively little attention in terms of vaccine design, although these cells are the primary targets of HIV infection and protecting them will inevitably interfere with this infection; such an effect could contribute to protection against the disease, mainly by controlling immunemediated inflammation and cell activation (Figure 2) [68$70]$.

Subdominant peptide epitopes from HIV-1 restricted to common HLA have been used in combination with an adjuvant to vaccinate treatment-naive HIV-1-infected individuals. New HIV-1 specific $\mathrm{CD} 4^{+}$and $\mathrm{CD} 8^{+} \mathrm{T}$-cell responses were induced in all patients; however, there were no significant changes to HIV-1 viral load or the $\mathrm{CD}^{+} \mathrm{T}$-cell count [71]. This highlights the importance of selecting optimum peptides for vaccination, because of the problem of HIV-1 diversity. This challenge could be resolved using inert mosaic sequences created by computer algorithms to maximize the coverage of potential epitopes from worldwide strains [72]. Studies in macaques have shown that mosaic sequences can enhance T-cell responses, but they have not yet been evaluated in humans, and the immune response they will elicit remains 
unknown [73]. In an attempt to address the issue of HIV1 diversity, highly conserved motifs can also be used to elicit immune responses capable of recognizing viruses from multiple clades.

Here, we briefly review the most representative peptide vaccine approaches tested to date:

(i) A C4-V3 polyvalent peptide vaccine comprising four peptides which contain T-helper epitopes from four constant regions of gp120, all HLA-B7-restricted cytotoxic T-lymphocytes and B-cell neutralizing epitopes from the gp120 variable region (V3) of four clade B isolates. A pilot Phase I study (DATRI-010) in $10 \mathrm{HIV-infected} \mathrm{patients}$ revealed both immunogenicity and safety in the patients, with no modulation of the $\mathrm{CD} 4^{+} \mathrm{T}$-cell count or plasma HIV RNA levels [74].

(ii) Vacc-4x is based on four synthetic peptides corresponding to HLA-A2-restricted conserved domains of the HIV-1 protein p24. A phase II randomized, doubleblind, placebo-controlled trial was performed in $136 \mathrm{HIV}-$ infected patients on cART who were randomly assigned
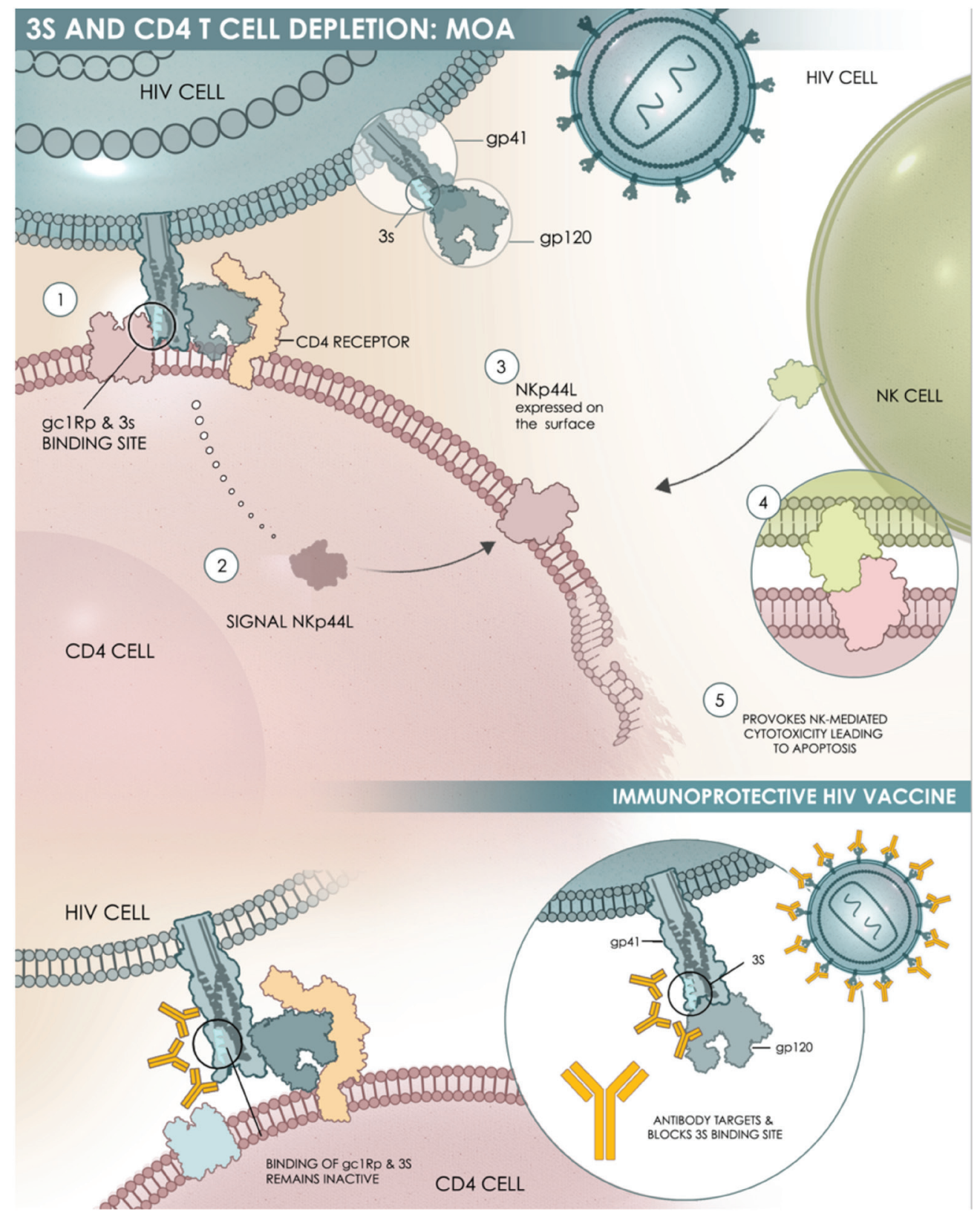

Figure 3: Schematic representation of the mechanism of action of 3S. The 3S motif of the gp41 envelope protein of HIV-1 acts through a subsequent cascade of interactions: Steps $1 \& 2$ : The $3 \mathrm{~S}$ motif binds to its specific receptor (gC1qR) on CD4 ${ }^{+} \mathrm{T}-\mathrm{cells}(\mathrm{CD} 4)$; Step 3: This interaction induces a molecular pathway that leads to NKp44L translocation at the surface of CD4+ T-cells; Steps 4 \& 5: the interaction between NKp44L and its receptor, with NKp44 expressed on activated NK cells, induces NK-mediated cytotoxicity and then $\mathrm{CD} 4^{+} \mathrm{T}$-cell depletion. 
to receive Vacc-4x. After the discontinuation of cART, a modest but significant reduction in viral load was noted, but the changes to $\mathrm{CD} 4^{+} \mathrm{T}$-cell counts were not significant, although proliferative responses were induced in both $\mathrm{CD}^{+}$and $\mathrm{CD}^{+} \mathrm{T}$-cell populations [75].

(iii) $\mathrm{VAC}-3 \mathrm{~S}$ is a peptide vaccine based on the highly specific and conserved $3 \mathrm{~S}$ motif localized in a gp41 HIV-1 region, exposed to the surface of the envelope protein (Pancera \& Kwong, NIAID, USA Personal communication). This motif interacts with the $\mathrm{gClqR}$, a receptor for the globular form of the $\mathrm{C} 1 \mathrm{q}$ complement factor, to induce both a decline of the $\mathrm{CD}^{+}$ T-cell count and an increase in viral load [26, 76]. In simian HIV (SHIV)-infected macaques immunized with the 3S-derived peptide, the decline of the $\mathrm{CD}^{+} \mathrm{T}$-cell count was prevented in both peripheral and secondary lymphoid tissues $[77,78]$. Alongside these observations, we highlighted an inhibition of immune inflammation (production of C-reactive protein, and TNF- $\alpha$ ) (personal data), and the activation and proliferation of $\mathrm{CD} 4^{+} \mathrm{T}$-cells, linked to a significant protection of central memory $\mathrm{CD}^{+}$ T-cells $[78,79]$. Overall, these data revealed a mechanism of action for the $3 \mathrm{~S}$ motif composed of successive steps, which are outlined in Figure 3. Blocking this pathway in $\mathrm{HIV}$-infected patients could protect $\mathrm{CD}^{+}{ }^{+} \mathrm{T}$-cells and decrease immune activation and inflammation, thereby achieving immune protection and restoring immune homeostasis. A First-In-Human study performed in 33 $\mathrm{HIV}$-infected patients under cART revealed that VAC$3 \mathrm{~S}$ is immunogenic and safe [80]. Significant changes from baseline in VAC-3S vaccine responders were observed (increase in the percentage of $\mathrm{CD}^{+} \mathrm{T}$-cells and in the $\mathrm{CD}^{+} / \mathrm{CD}^{+} \mathrm{T}$-cell ratio, reduction of total proviral DNA) indicating that this therapeutic vaccine approach is of interest (manuscript in preparation) [81, 82]. An international phase II, randomized, double-blind, placebo-controlled study is currently evaluating the safety, tolerability and immunogenicity of three different VAC-3S immunization schemes in 90 virologically-controlled HIV1 infected patients with $\mathrm{CD}^{+} \mathrm{T}$-cell counts of between 200 and 500 cells $/ \mathrm{mm}^{3}$ [ClinicalTrials.gov identifier NCT02041247] [83].

The studies performed to date have demonstrated that safe and effective vaccines based on a highly conserved motif are possible; they can protect $\mathrm{CD}^{+}$ T-cells and have made important contributions to our understanding of the path towards developing such a vaccine with immune homeostatic properties.

\section{What about antibody therapy?}

Antibodies (Abs) are used to either enhance immune responses or inhibit negative regulatory pathways. The ultimate goal is to reduce inflammation, prevent immune activation by HIV-1 and promote immune responses. This can be illustrated in three different situations, which reflect some putative new concepts:

(i) The therapeutic blocking of PD-1 and CTLA4: Programmed cell death 1 (PD1) and cytotoxic T-lymphocyte antigen 4 (CTLA4) are over-expressed in $\mathrm{CD}^{+} \mathrm{T}$-cells, and more particularly in the memory cells of all infected subjects, except elite controllers. The administration of monoclonal Abs (mAbs) to block PD-1 during chronic SIV infection in macaques prolonged survival; it also reduced immune over-activation and the expression of type 1 IFN stimulated genes, and enhanced immunity to gut-associated pathogens $[84,85]$. Similarly, the administration of an anti-PD-1 ligand promoted a lower rebound viral load in infected macaques [86].

The results obtained with anti-CTLA-4 mAbs in macaques were unfortunately less encouraging, with an increased activation of $\mathrm{CD}^{+} \mathrm{T}$-cells and viral replication at mucosal sites [87].

(ii) The lesson of RV144: in this vaccine, which is able to confer protection of $30 \%$ against HIV-1 acquisition [88], Env-directed IgA Abs can block the IgG-mediated antibody-dependent cellular cytotoxicity (ADCC) effector function [89, 90]. While the underlying mechanism remains unclear, non-neutralizing Abs may offer protection through effector functions such as ADCC, which occur in conjunction with cells of the innate immune system [91]. While much work remains, these new results represent potentially crucial clues to better understanding the protective function of Abs in the context of HIV-1.

(iii) The role of HIV-1 broadly neutralizing Abs: our understanding of what constitutes a broadly neutralizing antibody against HIV has recently been revolutionized by the isolation of extremely broad and potent neutralizing $\mathrm{mAb}$ from HIV-infected individuals [92-96]. Few of them are being studied in man regarding the protective therapeutic benefit of passive immunization [97-100]. While their infusions are well-tolerated, transient decreases of viral load have been observed, in line with the pharmacokinetics of the antibodies [99, 100]. One issue concerns the emergence of resistant HIV-1 viruses, so it is necessary to either combine broadly neutralizing mAbs together or with other immunotherapies.

(iv) The role of anti-3S Abs: These are inversely associated with the rate of $\mathrm{CD}^{+} \mathrm{T}$-cell count decrease, although they do not neutralize the virus [101]. Importantly, patients with high levels of anti-3S Abs experience a significantly delayed progression to $\mathrm{CD}^{+}$ T-cell levels below 200 cells $/ \mathrm{mm}^{3}$, and a very significantly lower level of cellular viral DNA [102]. Taken together, these data have led us to propose a possible application for anti-3S Abs as a "functional cure" [103]. Although much work still needs to be done, these new results offer potentially important clues to a clearer understanding the function of Abs during HIV-1 progression. 


\section{What about other immunotherapies?}

The strategies described above that are used to block various immune pathways need to be investigated in more depth, as does their potential synergy with other clinical approaches. In particular, in order to achieve a more efficient HIV cure, immunotherapy strategies could be combined with new types of drug such as the toll-like receptor 7 (TLR7) agonist, which can induce a transient activation of $\mathrm{CD}^{+}$T-cells (and of $\mathrm{CD}^{+}$and NK cells) and reduce the amount of viral DNA within cells from HIV-positive donors on cART [104], or by using a TLR9 agonist capable of reducing the viral reservoir in HIVinfected patients and enhancing HIV-specific CD8 ${ }^{+}$T-cell immunity [105].

\section{CONCLUSIONS}

The current clinical and therapeutic picture of HIV infection argues strongly in favor of new strategies that could promote restoration of the immune defenses. We hypothesize that an immunotherapeutic strategy enabling the re-establishment of T-cell homeostasis in HIV-infected patients is necessary to permit a sustainable peripheral and central control of viral burst in the context of a "functional cure". Indeed, immunotherapeutic approaches that can directly enhance effector functions against HIV and/or HIV-infected cells could be combined, and their expected synergy with immunotherapies would result in immune restoration. At all events, future progress will depend on an iterative relationship between novel findings from preclinical studies, including the impact in innate and other immune effector participants beyond conventional $\mathrm{CD}^{+}$and $\mathrm{CD}^{+}{ }^{-}$T-cells [90], and the proposal of combined, multiple immune-based therapeutic strategies to fight HIV disease and enable patients to be off therapy for long periods of time.

\section{ACKNOWLEDGMENTS}

The work is supported by grants from the French Agence National de la Recherche sur le SIDA et les Hépatites Virales (ANRS) and Agence Nationale de la Recherche (ANR).

The authors acknowledge the assistance of Victoria Hawken (Bolney, UK) regarding English language editing of the manuscript. Lynsey Ekema (Graniteville, USA) is the medical illustrator of Figure 3.

\section{CONFLICTS OF INTERESTS}

SG has been consultant for InnaVirVax. RHTF is employee of InnaVirVax. JC is founder, Chief Executive Officer and shareholder of InnaVirVax. PD and VV are founders and shareholders of InnaVirVax. All other authors declare no conflict of interests.

\section{REFERENCES}

1. Pinkevych M, Cromer D, Tolstrup M, Grimm AJ, Cooper DA, Lewin SR, Søgaard OS, Rasmussen TA, Kent SJ, Kelleher AD, Davenport MP. HIV Reactivation from Latency after Treatment Interruption Occurs on Average Every 5-8 Days-Implications for HIV Remission. PLoS Pathog. 2015; 11: e1005000.

2. Guiguet M, Boué F, Cadranel J, Lang JM, Rosenthal E, Costagliola D; Clinical Epidemiology Group of the FHDHANRS CO4 cohort. Clinical Epidemiology Group of the FHDH-ANRS CO4 cohort. Effect of immunodeficiency, HIV viral load, and antiretroviral therapy on the risk of individual malignancies (FHDH-ANRS CO4): a prospective cohort study. Lancet Oncol. 2009; 10: 1152-1159.

3. Whitney JB, Hill AL, Sanisetty S, Penaloza-MacMaster P, Liu J, Shetty M, Parenteau L, Cabral C, Shields J, Blackmore S, Smith JY, Brinkman AL, Peter LE, et al. Rapid seeding of the viral reservoir prior to SIV viraemia in rhesus monkeys. Nature. 2014; 512: 74-77.

4. Lorenzo-Redondo R, Fryer HR, Bedford T, Kim EY, Archer J, Kosakovsky Pond SL, Chung YS, Penugonda S, Chipman JG, Fletcher CV, Schacker TW, Malim MH, et al. Persistent HIV-1 replication maintains the tissue reservoir during therapy. Nature. 2016;530: 51-56.

5. Hütter G, Nowak D, Mossner M, Ganepola S, Müssig A, Allers K, Schneider T, Hofmann J, Kücherer C, Blau O, Blau IW, Hofmann WK, Thiel E. Long-term control of HIV by CCR5 Delta32/Delta32 stem-cell transplantation. N Engl J Med. 2009; 360: 692-698.

6. Symons J, Vandekerckhove L, Hütter G, Wensing AM, van Ham PM, Deeks SG, Nijhuis M. Dependence on the CCR5 coreceptor for viral replication explains the lack of rebound of CXCR4-predicted HIV variants in the Berlin patient. Clin Infect Dis. 2014; 59: 596-600.

7. Rasmussen TA, Tolstrup M, Brinkmann CR, Olesen R, Erikstrup C, Solomon A, Winckelmann A, Palmer S, Dinarello C, Buzon M, Lichterfeld M, Lewin SR, Østergaard L, Søgaard OS. Panobinostat, a histone deacetylase inhibitor, for latent-virus reactivation in HIVinfected patients on suppressive antiretroviral therapy: a phase 1/2, single group, clinical trial. Lancet HIV. 2014; 1: e13-e21

8. Katlama C, Deeks SG, Autran B, Martinez-Picado J, van Lunzen J, Rouzioux C, Miller M, Vella S, Schmitz JE, Ahlers J, Richman DD, Sekaly RP. Barriers to a cure for HIV: new ways to target and eradicate HIV-1 reservoirs. Lancet. 2013; 381: 2109-2117.

9. Siliciano JD, Siliciano RF. Recent developments in the search for a cure for HIV-1 infection: targeting the latent reservoir for HIV-1. J Allergy Clin Immunol. 2014; 134: 12-19. 
10. Dahabieh MS, Battivelli E, Verdin E. Understanding HIV latency: the road to an HIV cure. Annu Rev Med. 2015; 66: 407-421.

11. Søgaard OS, Graversen ME, Leth S, Olesen R, Brinkmann CR, Nissen SK, Kjaer AS, Schleimann MH, Denton PW, Hey-Cunningham WJ, Koelsch KK, Pantaleo G, Krogsgaard K, et al. The Depsipeptide Romidepsin Reverses HIV-1 Latency In Vivo. PLoS Pathog. 2015; 11: e1005142.

12. International AIDS Society Scientific Working Group on HIV Cure, Deeks SG, Autran B, Berkhout B, Benkirane M, Cairns S, Chomont N, Chun TW, Churchill M, Di Mascio M, Katlama C, Lafeuillade A, Landay A, et al. Towards an HIV cure: a global scientific strategy. Nat Rev Immunol. 2012; 12: 607-614.

13. Grabar S, Selinger-Leneman H, Abgrall S, Pialoux G, Weiss L, Costagliola D. Prevalence and comparative characteristics of long-term nonprogressors and HIV controller patients in the French Hospital Database on HIV. AIDS. 2009; 23: 1163-1169.

14. Saag M, Deeks SG. How do HIV elite controllers do what they do? Clin Infect Dis. 2010; 51: 239-241.

15. Sáez-Cirión A, Bacchus C, Hocqueloux L, AvettandFenoel V, Girault I, Lecuroux C, Potard V, Versmisse P, Melard A, Prazuck T, Descours B, Guergnon J, Viard JP, et al. Post-treatment HIV-1 controllers with a long-term virological remission after the interruption of early initiated antiretroviral therapy ANRS VISCONTI Study. PLoS Pathog. 2013; 9: e1003211.

16. Okulicz JF, Le TD, Agan BK, Camargo JF, Landrum ML, Wright E, Dolan MJ, Ganesan A, Ferguson TM, Smith DM, Richman DD, Little SJ, Clark RA, He W, Ahuja SK. Influence of the timing of antiretroviral therapy on the potential for normalization of immune status in human immunodeficiency virus 1-infected individuals. JAMA Intern Med. 2015; 175: 88-99.

17. Chun TW, Moir S, Fauci AS. HIV reservoirs as obstacles and opportunities for an HIV cure. Nat Immunol. 2015; 16: 584-589.

18. Klatt NR, Chomont N, Douek DC, Deeks SG. Immune activation and HIV persistence: implications for curative approaches to HIV infection. Immunol Rev. 2013; 254: 326-342.

19. Buzón MJ, Massanella M, Llibre JM, Esteve A, Dahl V, Puertas MC, Gatell JM, Domingo P, Paredes R, Sharkey M, Palmer S, Stevenson M, Clotet B, Blanco J, MartinezPicado J. HIV-1 replication and immune dynamics are affected by raltegravir intensification of HAARTsuppressed subjects. Nat Med. 2010; 16: 460-465.

20. Hatano H, Hayes TL, Dahl V, Sinclair E, Lee TH, Hoh R, Lampiris H, Hunt PW, Palmer S, McCune JM, Martin JN, Busch MP, Shacklett BL, Deeks SG. A randomized, controlled trial of raltegravir intensification in antiretroviraltreated, HIV-infected patients with a suboptimal CD4+ T cell response. J Infect Dis. 2011; 203: 960-968.
21. INSIGHT START Study Group. Lundgren JD, Babiker AG, Gordin F, Emery S, Grund B, Sharma S, Avihingsanon A, Cooper DA, Fätkenheuer G, Llibre JM, Molina JM, Munderi P, et al. Initiation of Antiretroviral Therapy in Early Asymptomatic HIV Infection. N Engl J Med. 2015; 373: 795-807.

22. Simon V, Ho DD. HIV-1 dynamics in vivo: implications for therapy. Nat Rev Microbiol. 2003; 1: 181-190.

23. Levy JA. HIV and the Pathogenesis of AIDS. 3rd Edition. Washington DC: ASM Press, 2007.

24. Alimonti JB, Ball TB, Fowke KR. Mechanisms of CD4+ $\mathrm{T}$ lymphocyte cell death in human immunodeficiency virus infection and AIDS. J Gen Virol. 2003; 84: 1649-1661.

25. Baychelier F, Sennepin A, Ermonval M, Dorgham K, Debré P, Vieillard V. Identification of a cellular ligand for the natural cytotoxicity receptor NKp44. Blood. 2013; 122: 2935-2942.

26. Vieillard V, Strominger JL, Debré P. NK cytotoxicity against CD4+ $\mathrm{T}$ cells during HIV-1 infection: a gp41 peptide induces the expression of an NKp44 ligand. Proc Natl Acad Sci U S A. 2005; 102: 10981-10986.

27. Sennepin A, Baychelier F, Guihot A, Nel I, Ho Tsong Fang R, Calin R, Katlama C, Simon A, Crouzet J, Debré $\mathrm{P}$, Vieillard V. NKp44L expression on CD4+ T cells is associated with impaired immunological recovery in HIVinfected patients under highly active antiretroviral therapy. AIDS. 2013; 27: 1857-1866.

28. Ward J, Bonaparte M, Sacks J, Guterman J, Fogli M, Mavilio D, Barker E. HIV modulates the expression of ligands important in triggering natural killer cell cytotoxic responses on infected primary T-cell blasts. Blood. 2007; 110: 1207-1214.

29. Fausther-Bovendo H, Sol-Foulon N, Candotti D, Agut H, Schwartz O, Debré P, Vieillard V. HIV escape from natural killer cytotoxicity: nef inhibits NKp44L expression on CD4+ T cells. AIDS. 2009; 23: 1077-1087.

30. Appay V, Sauce D. Immune activation and inflammation in HIV-1 infection: causes and consequences. J Pathol. 2008; 214: 231-241.

31. Deeks SG. HIV infection, inflammation, immunosenescence, and aging. Ann Rev Med. 2011; 62: 141-155.

32. Appay V, Almeida JR, Sauce D, Autran B, Papagno L. Accelerated immune senescence and HIV-1 infection. Exp Gerontol. 2007; 42: 432-437.

33. Gonzalez VD, Falconer K, Blom KG, Reichard O, Mørn B, Laursen AL, Weis N, Alaeus A, Sandberg JK. High levels of chronic immune activation in the T-cell compartments of patients coinfected with hepatitis $\mathrm{C}$ virus and human immunodeficiency virus type 1 and on highly active antiretroviral therapy are reverted by alpha interferon and ribavirin treatment. J Virol. 2009; 83: 11407-11411.

34. Lichtner M, Cicconi P, Vita S, Cozzi-Lepri A, Galli M, Lo Caputo S, Saracino A, De Luca A, Moioli M, Maggiolo 
F, Marchetti G, Vullo V, d'Arminio Monforte A; ICONA Foundation Study. Cytomegalovirus coinfection is associated with an increased risk of severe non-AIDSdefining events in a large cohort of HIV-infected patients. J Infect Dis. 2015; 211: 178-186.

35. BenMarzouk-Hidalgo OJ, Torres-Cornejo A, GutiérrezValencia A, Ruiz-Valderas R, Viciana P, López-Cortés LF. Differential effects of viremia and microbial translocation on immune activation in HIV-infected patients throughout ritonavir-boosted darunavir monotherapy. Medicine (Baltimore). 2015; 94: e781.

36. Nowak P, Troseid M, Avershina E, Barqasho B, Neogi U, Holm K, Hov JR, Noyan K, Vesterbacka J, Svärd J, Rudi K, Sönnerborg A. Gut microbiota diversity predicts immune status in HIV-1 infection. AIDS. 2015; 29: 2409-2418.

37. Brenchley JM, Schacker TW, Ruff LE, Price DA, Taylor JH, Beilman GJ, Nguyen PL, Khoruts A, Larson M, Haase AT, Douek DC. CD4+ T cell depletion during all stages of HIV disease occurs predominantly in the gastrointestinal tract. J Exp Med. 2004; 200: 749-759.

38. Assimakopoulos SF, Dimitropoulou D, Marangos M, Gogos CA. Intestinal barrier dysfunction in HIV infection: pathophysiology, clinical implications and potential therapies. Infection. 2014; 42: 951-959.

39. Mehandru S, Poles MA, Tenner-Racz K, Jean-Pierre P, Manuelli V, Lopez P, Shet A, Low A, Mohri H, Boden D, Racz P, Markowitz M. Lack of mucosal immune reconstitution during prolonged treatment of acute and early HIV-1 infection. PLoS Med. 2006; 3: e484.

40. Mavigner M, Cazabat M, Dubois M, L'Faqihi FE, Requena M, Pasquier C, Klopp P, Amar J, Alric L, Barange K, Vinel JP, Marchou B, Massip P, Izopet J, Delobel P. Altered CD4+ T cell homing to the gut impairs mucosal immune reconstitution in treated HIV-infected individuals. J Clin Invest. 2012; 122: 62-69.

41. Cossarizza A, Poccia F, Agrati C, D’Offizi G, Bugarini R, Pinti M, Borghi V, Mussini C, Esposito R, Ippolito G, Narciso P. Highly active antiretroviral therapy restores CD4+ Vbeta T-cell repertoire in patients with primary acute HIV infection but not in treatment-naive HIV+ patients with sevechronic infection. J Acquir Immune Defic Syndr. 2004; 35: 213-222.

42. Vrisekoop N, van Gent R, de Boer AB, Otto SA, Borleffs JC, Steingrover R, Prins JM, Kuijpers TW, Wolfs TF, Geelen SP, Vulto I, Lansdorp P, Tesselaar K, Borghans JA, Miedema F. Restoration of the CD4 T cell compartment after long-term highly active antiretroviral therapy without phenotypical signs of accelerated immunological aging. J Immunol. 2008; 181: 1573-1581.

43. Yin L, Kou ZC, Rodriguez C, Hou W, Goodenow MM, Sleasman JW. Antiretroviral therapy restores diversity in the T-cell receptor Vbeta repertoire of CD4 T-cell subpopulations among human immunodeficiency virus type 1 -infected children and adolescents. Clin Vaccine Immunol. 2009; 16: 1293-1301.
44. Carcelain G, Autran B. Immune interventions in HIV infection. Immunol Rev. 2013; 254: 355-371.

45. Archin NM, Vaidya NK, Kuruc JD, Liberty AL, Wiegand A, Kearney MF, Cohen MS, Coffin JM, Bosch RJ, Gay CL, Eron JJ, Margolis DM, Perelson AS. Immediate antiviral therapy appears to restrict resting CD4+ cell HIV-1 infection without accelerating the decay of latent infection. Proc Acad Natl Sci U S A. 2012; 109: 9523-9528.

46. Molina JM, Levy Y, Fournier I, Hamonic S, Bentata M, Beck-Wirth G, Gougeon ML, Venet A, Madelaine I, Sereni D, Jeanblanc F, Boulet T, Simon F, Aboulker JP; Agence Nationale de Recherches sur le SIDA et les Hépatites Virales (ANRS) 119 Interstart Study Team. Interleukin-2 before antiretroviral therapy in patients with HIV infection: a randomized trial (ANRS 119). J Infect Dis. 2009; 200: 206-215.

47. INSIGHT-ESPRIT Study Group; SILCAAT Scientific Committee, Abrams D, Lévy Y, Losso MH, Babiker A, Collins G, Cooper DA, Darbyshire J, Emery S, Fox L, Gordin F, Lane HC, et al. Interleukin-2 therapy in patients with HIV infection. N Engl J Med. 2009; 361: 1548-1559.

48. Weiss L, Letimier FA, Carriere M, Maiella S, DonkovaPetrini V, Targat B, Benecke A, Rogge L, Levy Y. In vivo expansion of naive and activated CD4+CD25+FOXP3+ regulatory $\mathrm{T}$ cell populations in interleukin-2-treated HIV patients. Proc Natl Acad Sci U S A. 2010; 107: 1063210637.

49. Levy Y, Lacabaratz C, Weiss L, Viard JP, Goujard C, Lelièvre JD, Boué F, Molina JM, Rouzioux C, AvettandFénoêl V, Croughs T, Beq S, Thiébaut R, Chêne G, Morre M, Delfraissy JF. Enhanced T cell recovery in HIV-1infected adults through IL-7 treatment. J Clin Invest. 2009; 119: 997-1007.

50. Levey Y, Sereti I, Tambussi G, Routy JP, Lelièvre JD, Delfraissy JF, Molina JM, Fischl M, Goujard C, Rodriguez B, Rouzioux C, Avettand-Fenoël V, Croughs T, et al. Effects of recombinant human interleukin 7 on T-cell recovery and thymic output in HIV-infected patients receiving antiretroviral therapy: results of a phase I/IIa randomized, placebo-controlled, multicenter study. Clin Infect Dis. 2012; 55: 291-300.

51. Croce M, Orengo AM, Azzarone B, Ferrini S. Immunotherapeutic applications of IL-15. Immunotherapy. 2012; 4: 957-969.

52. Li J, Valentin A, Ng S, Beach RK, Alicea C, Bergamaschi C, Felber BK, Pavlakis GN. Differential effects of IL-15 on the generation, maintenance and cytotoxic potential of adaptive cellular responses induced by DNA vaccination. Vaccine. 2015; 33: 1188-1196.

53. Pallikkuth S, Micci L, Ende ZS, Iriele RI, Cervasi B, Lawson B, McGary CS, Rogers KA, Else JG, Silvestri G, Easley K, Estes JD, Villinger F, Pahwa S, Paiardini M. Maintenance of intestinal Th17 cells and reduced microbial translocation in SIV-infected rhesus macaques treated with interleukin (IL)-21. PLoS Pathog. 2013; 9: e1003471. 
54. Herasimtschuk A, Downey J, Nelson M, Moyle G, Mandalia S, Sikut R, Adojaan M, Stanescu I, Gotch F, Imami N. Therapeutic immunisation plus cytokine and hormone therapy improves CD4 T-cell counts, restores antiHIV-1 responses and reduces immune activation in treated chronic HIV-1 infection. Vaccine. 2014; 32: 7005-7013.

55. Jefferys R. Research Toword a Cure and Immune-based and gene-therapies. HIV i-base/treatment action group. 2015 Pipeline report. pp81-101.

56. Li JZ, Brumme ZL, Brumme CJ, Wang H, Spritzler J, Robertson MN, Lederman MM, Carrington M, Walker BD, Schooley RT, Kuritzkes DR; AIDS Clinical Trials Group A5197 Study Team. Factors associated with viral rebound in HIV-1-infected individuals enrolled in a therapeutic HIV-1 gag vaccine trial. J Infect Dis. 2011; 203: 976-983.

57. Li JZ, Brumme CJ, Lederman MM, Brumme ZL, Wang H, Spritzler J, Carrington M, Medvik K, Walker BD, Schooley RT, Kuritzkes DR; AIDS Clinical Trials Group A5197 Study Team. Characteristics and outcomes of initial virologic suppressors during analytic treatment interruption in a therapeutic HIV-1 gag vaccine trial. PLoS One. 2012; 7: e34134.

58. Ensoli B, Fiorelli V, Ensoli F, Lazzarin A, Visintini R, Narciso P, Di Carlo A, Monini P, Magnani M, Garaci E. The therapeutic phase I trial of the recombinant native HIV1 Tat protein. AIDS. 2008; 22: 2207-2209.

59. Ensoli B, Fiorelli V, Ensoli F, Lazzarin A, Visintini R, Narciso P, Di Carlo A, Tripiciano A, Longo O, Bellino S, Francavilla V, Paniccia G, Arancio A, et al. The preventive phase I trial with the HIV-1 Tat-based vaccine. Vaccine. 2009; 28: 371-378.

60. Lisziewicz J, Trocio J, Xu J, Whitman L, Ryder A, Bakare N, Lewis MG, Wagner W, Pistorio A, Arya S, Lori F. Control of viral rebound through therapeutic immunization with DermaVir. AIDS. 2005; 19: 35-43.

61. Cristillo AD, Lisziewicz J, He L, Lori F, Galmin L, Trocio JN, Unangst T, Whitman L, Hudacik L, Bakare N, Whitney S, Restrepo S, Suschak J, et al. HIV-1 prophylactic vaccine comprised of topical DermaVir prime and protein boost elicits cellular immune responses and controls pathogenic R5 SHIV162P3. Virology. 2007; 366: 197-211.

62. Rodriguez B, Asmuth DM, Matining RM, Spritzler J, Jacobson JM, Mailliard RB, Li XD, Martinez AI, Tenorio AR, Lori F, Lisziewicz J, Yesmin S, Rinaldo CR, Pollard RB. Safety, tolerability, and immunogenicity of repeated doses of dermavir, a candidate therapeutic HIV vaccine, in HIV-infected patients receiving combination antiretroviral therapy: results of the ACTG 5176 trial. J Acquir Immune Defic Syndr. 2013; 64: 351-359.

63. Andrés C, Plana M, Guardo AC, Alvarez-Fernández C, Climent N, Gallart T, León A, Clotet B, Autran B, Chomont N, Gatell JM, Sánchez-Palomino S, García F. HIV-1 Reservoir Dynamics after Vaccination and Antiretroviral Therapy Interruption Are Associated with Dendritic Cell Vaccine-Induced T Cell Responses. J Virol. 2015; 89:
9189-9199.

64. Wilson CC, McKinney D, Anders M, MaWhinney S, Forster J, Crimi C, Southwood S, Sette A, Chesnut R, Newman MJ, Livingston BD. Development of a DNA vaccine designed to induce cytotoxic $\mathrm{T}$ lymphocyte responses to multiple conserved epitopes in HIV-1. J Immunol. 2003; 171: 5611 5623.

65. Shiu C, Cunningham CK, Greenough T, Muresan $\mathrm{P}$, Sanchez-Merino V, Carey V, Jackson JB, Ziemniak C, Fox L, Belzer M, Ray SC, Luzuriaga K, Persaud D; Pediatric AIDS Clinical Trials Group P1059 Team. Identification of ongoing human immunodeficiency virus type 1 (HIV1) replication in residual viremia during recombinant HIV-1 poxvirus immunizations in patients with clinically undetectable viral loads on durable suppressive highly active antiretroviral therapy. J Virol. 2009; 83: 9731-9742.

66. Barouch DH, Picker LJ. Novel vaccine vectors for HIV-1. Nat Rev Microbiol. 2014; 12: 765-771.

67. Vardas E, Stanescu I, Leinonen M, Ellefsen K, Pantaleo G, Valtavaara M, Ustav M, Reijonen K. Indicators of therapeutic effect in FIT-06, a Phase II trial of a DNA vaccine, GTU $\left({ }^{\circledR}\right)$-Multi-HIVB, in untreated HIV-1 infected subjects. Vaccine. 2012; 30: 4046-4654.

68. Ensoli B, Cafaro A, Monini P, Marcotullio S, Ensoli F. Challenges in HIV Vaccine Research for Treatment and Prevention. Front Immunol. 2014; 5: 417.

69. Graziani GM, Angel JB. Evaluating the efficacy of therapeutic HIV vaccines through analytical treatment interruptions. J Int AIDS Soc. 2015; 18: 20497.

70. Mylvaganam GH, Silvestri G, Amara RR. HIV therapeutic vaccines: moving towards a functional cure. Curr Opin Immunol. 2015; 35: 1-8.

71. Karlsson I, Brandt L, Vinner L, Kromann I, Andreasen LV, Andersen P, Gerstoft J, Kronborg G, Fomsgaard A. Adjuvanted HLA-supertype restricted subdominant peptides induce new T-cell immunity during untreated HIV1-infection. Clin Immunol. 2013; 146: 120-130.

72. Excler JL, Robb ML, Kim JH. Prospects for a globally effective HIV-1 vaccine. Vaccine 2015; 33 Suppl 4: D4D12.

73. Barouch DH, O'Brien KL, Simmons NL, King SL, Abbink P, Maxfield LF, Sun YH, La Porte A, Riggs AM, Lynch DM, Clark SL, Backus K, Perry JR, et al. Mosaic HIV-1 vaccines expand the breadth and depth of cellular immune responses in rhesus monkeys. Nat Med. 2010; 16: 319-323.

74. Bartlett JA, Wasserman SS, Hicks CB, Dodge RT, Weinhold KJ, Tacket CO, Ketter N, Wittek AE, Palker TJ, Haynes BF. Safety and immunogenicity of an HLA-based HIV envelope polyvalent synthetic peptide immunogen. DATRI 010 Study Group. Division of AIDS Treatment Research Initiative. AIDS. 1998; 12: 1291-300.

75. Pollard RB, Rockstroh JK, Pantaleo G, Asmuth DM, Peters B, Lazzarin A, Garcia F, Ellefsen K, Podzamczer D, van Lunzen J, Arastéh K, Schürmann D, Clotet B, et al. Safety 
and efficacy of the peptide-based therapeutic vaccine for HIV-1, Vacc-4x: a phase 2 randomised, double-blind, placebo-controlled trial. Lancet Infect Dis. 2014; 14: 291 300.

76. Fausther-Bovendo H, Vieillard V, Sagan S, Bismuth G, Debré P. HIV gp41 engages gC1qR on CD4+ T cells to induce the expression of an NK ligand through the PIP3/ H2O2 pathway. PLoS Pathog. 2010; 6: e1000975.

77. Vieillard V, Habib RE, Brochard P, Delache B, Bovendo HF, Calvo J, Morin J, Picq I, Martinon F, Vaslin B, Le Grand R, Debré P. CCR5 or CXCR4 use influences the relationship between CD4 cell depletion, NKp44L expression and NK cytotoxicity in SHIV-infected macaques. AIDS. 2008; 22: 185-192.

78. Vieillard V, Dereuddre-Bosquet N, Mangeot-Méderlé I, Le Grand R, Debré P. An HIVgp41 vaccine protects CD4 central memory $\mathrm{T}$ cells in SHIV-infected macaques. Vaccine. 2012; 30: 6883-6891.

79. Vieillard V, Le Grand R, Dausset J, Debré P. A vaccine strategy against AIDS: an HIV gp41 peptide immunization prevents NKp44L expression and CD4+ T cell depletion in SHIV-infected macaques. Proc Natl Acad Sci U S A. 2008; 105: 2100-2104.

80. Gharakhanian S. Katlama K, Launey O, Bodilis H, Calin R. Fang R, Marcu M, Autran B, Vieillard V, Crouzet J. VAC-3S, an immunoprotecive HIV Vaccine directed to the $3 \mathrm{~S}$ motif of gp41, in patients receiving ART: safety, dose and immunization schedule assessment. AIDS Vaccine Conference 2013, 7-10 October, Barcelona, Spain. [Poster \#13.57].

81. Katlama C, Launay O, Ho Tsong Fang R, Bodilis H, Calin R, Autran B, Gharakhanian S, Vieillard V, Crouzet J, Debre P. A randomized, placebo-controlled, double-blind, phase I/IIa dose escalation study of an HIV immunotherapeutic vaccine, VAC-3S, directed to the gp41 3S motif of HIV1. 20th Conference on Retroviruses and Opportunistic Infections (CROI). Atlanta, Georgia, 3-6March, 2013. [Abstract \#392].

82. Ho Tsong Fang R, Launay O, Katlama C, J Crouzet J, B Autran A, V Vieillard V, Debré P, Gharakhanian S. VAC$3 \mathrm{~S}$ vaccine, a novel approche to the theapeutoc management of HIV infection. Overview of phase I and phase II clinical vaccine development programs. J Vaccines 2014; 5: 5

83. Ho Tsong Fang R, Launay O, Rouzioux C, Autran B, Capeau J, Melard A, Marcu M, Calin R, Bodilis, H, Crouzet J, Vieillard V, Debre D, Gharakhanian S, Katlama C. VAC3S, a safe immunotherapeutic HIV vaccine decreased total HIV DNA ad increased CD4/CD8 ratio: phase I final results. Towards an HIV Cure Symposium, 2015, 18-19 July, IAS: Vancouver, Canada. [Poster \#PE67-LB].

84. Macatangay BJ, Rinaldo CR. PD-1 blockade: A promising immunotherapy for HIV? CellsScience. 2009; 5: 61-65.

85. Dyavar Shetty R, Velu V, Titanji K Bosinger SE, Freeman GJ, Silvestri G, Amara RR. PD-1 blockade during chronic SIV infection reduces hyperimmune activation and microbial translocation in rhesus macaques. J Clin Invest. 2012; 122: 1712-1716.

86. Mason SW, Sanisetty S, Osuna C. Viral Suppression Induced by Anti-PDL1 Following ARV-Interruption in SIV-Infected Monkeys. 21st Conference on Retroviruses and Opportunistic Infections, March 3 - 6, 2014, Boston, MA. [Poster \#318LB].

87. Hryniewicz A, Boasso A, Edghill-Smith Y, Vaccari M, Fuchs D, Venzon D, Nacsa J, Betts MR, Tsai WP, Heraud JM, Beer B, Blanset D, Chougnet C, Lowy I, Shearer GM, Franchini G. CTLA-4 blockade decreases TGF-beta, IDO, and viral RNA expression in tissues of SIVmac251-infected macaques. Blood. 2006; 108: 3834-3842.

88. Rerks-Ngarm S, Pitisuttithum P, Nitayaphan S, Kaewkungwal J, Chiu J, Paris R, Premsri N, Namwat C, de Souza M, Adams E, Benenson M, Gurunathan S, Tartaglia $\mathrm{J}$, et al. Vaccination with ALVAC and AIDSVAX to prevent HIV-1 infection in Thailand. N Engl J Med. 2009; 361: 2209-2220.

89. Barouch DH, Liu J, Li H, Maxfield LF, Abbink P, Lynch DM, Iampietro MJ, SanMiguel A, Seaman MS, Ferrari G, Forthal DN, Ourmanov I, Hirsch VM, et al. Vaccine protection against acquisition of neutralization-resistant SIV challenges in rhesus monkeys. Nature. 2012; 482: 89-93.

90. Tomaras GD, Ferrari G, Shen X, Alam SM, Liao HX, Pollara J, Bonsignori M, Moody MA, Fong Y, Chen X, Poling B, Nicholson CO, Zhang R, et al. Vaccine-induced plasma IgA specific for the $\mathrm{C} 1$ region of the HIV-1 envelope blocks binding and effector function of IgG. Proc Natl Acad Sci U S A. 2013; 110: 9019-9024.

91. Ackerman ME, Dugast AS, Alter G. Emerging concepts on the role of innate immunity in the prevention and control of HIV infection. Annu Rev Med. 2012; 63: 113-130.

92. West AP Jr, Scharf L, Scheid JF, Klein F, Bjorkman PJ, Nussenzweig MC. Structural insights on the role of antibodies in HIV-1 vaccine and therapy. Cell. 2014; 156: 633-648.

93. Klein F, Nogueira L, Nishimura Y, Phad G, West AP Jr, Halper-Stromberg A, Horwitz JA, Gazumyan A, Liu C, Eisenreich TR, Lehmann C, Fätkenheuer G, Williams C, et al. Enhanced HIV-1 immunotherapy by commonly arising antibodies that target virus escape variants. J Exp Med. 2014; 211: 2361-2372.

94. Burton DR, Mascola JR. Antibody responses to envelope glycoproteins in HIV-1 infection. Nat Immunol. 2015; 16: 571-576.

95. Sadanand S, Suscovich TJ, Alter G. Broadly Neutralizing Antibodies Against HIV: New Insights to Inform Vaccine Design. Annu Rev Med. 2016; 67: 185-200.

96. Alter G, Barouch DH. Natural evolution of broadly neutralizing antibodies. Cell. 2015; 161: 427-428.

97. Zhou T, Georgiev I, Wu X, Yang ZY, Dai K, Finzi A, Kwon YD, Scheid JF, Shi W, Xu L, Yang Y, Zhu J, Nussenzweig MC, Sodroski J, Shapiro L, Nabel GJ, Mascola JR, Kwong 
PD. Structural basis for broad and potent neutralization of HIV-1 by antibody VRC01. Science. 2010; 329: 811-817.

98. Zhou T, Zhu J, Wu X, Moquin S, Zhang B, Acharya P, Georgiev IS, Altae-Tran HR, Chuang GY, Joyce MG, Kwon YD, Longo NS, Louder MK, et al. Multidonor analysis reveals structural elements, genetic determinants, and maturation pathway for HIV-1 neutralization by VRC01-class antibodies. Immunity. 2013; 39: 245-258.

99. Caskey M, Klein F, Lorenzi JC, Seaman MS, West AP Jr, Buckley N, Kremer G, Nogueira L, Braunschweig M, Scheid JF, Horwitz JA, Shimeliovich I, Ben-Avraham S, et al. Viraemia suppressed in HIV-1-infected humans by broadly neutralizing antibody 3BNC117. Nature. 2015; 522: 487-491.

100. Lynch RM, Boritz E, Coates EE, DeZure A, Madden P, Costner P, Enama ME, Plummer S, Holman L, Hendel CS, Gordon I, Casazza J, Conan-Cibotti M, et al. Virologic effects of broadly neutralizing antibody VRC01 administration during chronic HIV-1 infection. Sci Transl Med. 2015; 7: 319ra206.

101. Vieillard V, Costagliola D, Simon A, Debré P; French Asymptomatiques à Long Terme (ALT) Study Group. Specific adaptive humoral response against a gp41 motif inhibits CD4 T-cell sensitivity to NK lysis during HIV-1 infection. AIDS. 2006; 20: 1795-1804.

102. Vieillard V, Crouzet J, Boufassa F, Sennepin A, Ho Tsong Fang R, Debré P, Meyer L. Specific anti-gp41 antibodies predict HIV-1 disease progression. J Acquir Immune Defic Syndr. 2012; 61: 403-405.

103. Crouzet J, Vieillard V, Debre P, Katlama C, Launay O, Ho Tsong Fang R, Desfontaines- Batéjat D, Marcu M, Gharakhanian S. Potential role of anti-3S antibodies in an HIV medical cure strategy? Workshop on HIV Cure and Eradication. 24-25 January, 2013, Milan, Italy.

104. Sloan D, Irrinki A, Tsai A, Kaur J, Lalezari J, Murry J, Cihlar T. TLR7 Agonist GS-9620 Activates HIV-1 in PBMCs from HIV-Infected Patients on cART. 22th Conference on Retroviruses and Opportunistic Infections (CROI). 23- 26 February, 2015 Seattle, WA [Poster \#417].

105. Winckelmann AA, Munk-Petersen LV, Rasmussen TA, Melchjorsen J, Hjelholt TJ, Montefiori D, Østergaard L, Søgaard OS, Tolstrup M. Administration of a Tolllike receptor 9 agonist decreases the proviral reservoir in virologically suppressed HIV-infected patients. PLoS One. 2013; 8: e62074. 